\title{
Correlation between Serum Magnesium and Calcium Level in Children with Idiopathic Nephrotic Syndrome during Nephrosis
}

\author{
GULSHAN NIGAR CHAUDHURY ${ }^{1}$, MOHAMMED HANIF ${ }^{2}$, MAHENAZAFROZ $^{3}$, DILRUBA BEGUM ${ }^{4}$
}

\begin{abstract}
Background: Biochemical alteration is a common phenomenon in all kidney disease including nephrotic syndrome (NS).

Objective: To evaluate the magnesium (Mg) level in patients with nephrotic syndrome and its relation to calcium.

Methods: In this observational cross sectional study, we measured serum magnesium and serum calcium levels in children with nephrotic syndrome. It was conducted in the Department of Pediatrics, Dhaka Shishu(children) Hospital, Dhaka, from January 2015 to June 2015. A total of fifty four diagnosed cases of nephrotic syndrome were divided into initial episode, first relapse, infrequent relapse and frequent relapse. Mean level of serum magnesium and calcium of all four groups were then compared.

Results :The mean level of serum magnesium during initial episode was $2.28 \pm 0.36 \mathrm{mg} /$ $\mathrm{dl}$ and it was $2.04 \pm 0.29,2.06 \pm 0.29$ and $1.76 \pm 0.32 \mathrm{mg} / \mathrm{dl}$ during first relapse, infrequent relapse and frequent relapse respectively. The mean serum magnesium level in different patterns of nephrotic syndrome was found to be statistically significant. Hypomagnesemia was mostly found in frequent relapse nephrotic syndrome patients. The mean level of serum calcium during initial episode was $2.01 \pm 0.16$ and it was $1.98 \pm 0.17,2.06 \pm 0.13$ and $2.05 \pm 0.15$ during first relapse, infrequent relapse and frequent relapse respectively. The mean serum calcium level in different patterns of nephrotic syndrome was found to be statistically insignificant. There was no significant corelation between calcium level with magnesium level $(r=-0.08, p=0.28)$.

Conclusion: Hypomagnesemia is commonly found in frequent relapse nephrotic syndrome. There was no significant correlation between calcium with magnesium level.
\end{abstract}

Key words: Nephrotic syndrome, magnesium, calcium.

\section{Introduction}

Nephrotic syndrome patients frequently have abnormalities in calcium metabolism that manifest as hypocalcemia. Hypocalcemia is initially attributed to hypoalbuminemia but it may also relate to a low level of ionized calcium. ${ }^{1}$ Magnesium is needed for more than 300 biochemical reactions in the body. It

1. Resident Medical Officer, Department of Rheumatology, Dhaka Shishu (Children) Hospital.

2. Professor and Head of the Department of Nephrology, Dhaka Shishu (Children) Hospital, Dhaka.

3. Assistant Professor, Department of Gynae \& Obstetrics, National Institute for Cancer Research Hospital (NICRH), Dhaka.

4. Associate Professor, Department of Physiology, Dhaka Medical College, Dhaka.

Correspondence: Dr. Gulshan Nigar Chaudhury, Resident Medical Officer, Department of Rheumatology, Dhaka Shishu (Children) Hospital. Email: gulshan.chy@gmail.com helps maintain normal muscle and nerve function, keeps heart rhythm steady, supports a healthy immune system, and keeps bone strong. 2,3 Nephrotic syndrome (NS) is a clinical entity characterized by massive loss of urinary protein (primarily albuminuria) leading to hypoproteinemia resulting in edema. ${ }^{4,5}$

If the serum ionized calcium level declines below normal,clinical symptoms like neuromuscular irritability including tetany as manifested by chovstek's sign or Trousseau's sign. Patients with nephrotic syndrome (NS) lose 25-hydroxyvitamin D3 (25OHD3) in the urine and have low blood levels of this metabolite. ${ }^{6}$ The most frequent causes of hypomagnesemia in children are reduced intake, impaired intestinal absorption, renal loss and genetic disease. Severe hypomagnesemia induces secondary hypocalcemia in most experimental animals except 
rats. Furthermore, severe hypomagnesemia induces functional hypoparathyroidism. ${ }^{7}$

Magnesium supplement and testing may be ordered as a follow up to chronically low level of calcium and potassium and when a person has symptoms that may be due to magnesium deficiency such as muscle weakness, twitching, cramping, confusion, cardiac arrhythmia and seizure. .,9 $^{8}$ A particular long list of prescription medications have been shown to reduce the body's supply of magnesium. Several types of diuretics, loop diuretics like frusemide, antibiotic, corticosteroids and immuno-suppressant drug cyclosporine. ${ }^{2}$ So Magnesium level should be checked as a part of evaluation of the severity of the kidney problems. Proper supplementation of magnesium can properly manage the disease as they are altered in nephrotic syndrome. For these reasons the serum magnesium level in patients with idiopathic nephrotic syndrome is an important issue.

\section{Materials and Methods}

An observational cross sectional study was conducted in the Department of pediatrics Dhaka Shishu Hospital, Dhaka, from January 2015 to June 2015.A total of 54 diagnosed cases of nephrotic syndrome admitted in this hospital were included in this study.NS with associated illnesses such as diarrhoea, severe vomiting and those who already have metabolic disturbances and seizure were excluded from this study. Those who are taking calcium and vitamin $D$ were also excluded. Written informed consent was taken from each parent at the commencement of the study.Prior permission was taken for this study from the Ethical Committee of Dhaka Shisu Hospital, Dhaka, Bangladesh. This article was based on dissertation for FCPS (pediatrics).

All necessary investigations, diagnostic and infection screening like $C B C$, urine $R / M / E$, urine $C / S$, serum albumin, cholesterol, spot protein creatinine ratio, $\mathrm{Hbs}$ Ag. On admission, $2 \mathrm{ml}$ of blood was collected from each patient. Samples were centrifuged and stored in a refrigerator. Serum magnesium and calcium levels were assessed.

The 54 study children were then devided into 4 groups initial episode $(n=15)$,first relapse- those presented with first relapse after completion of steroid therapy of initial episode $(n=12)$, infrequent relapse-those presented with infrequent relapse following completion of steroid therapy of first relapse $(n=13)$, frequent relapse-those had history of more than or equal to 4 relapse during the last year $(n=14)$.

The magnesium was measured by Magnesium(MG) method, that was used on the Dimension(R) clinical chemistry system. It is an in vitro diagnostic test intended for the quantitative determination of magnesium in human serum, plasma and urine. The magnesium method is a modification of the methylthymolblue(MTB) complexometric procedure described by Connerty, Lau and Briggs. The barium salt of ethylenebis (oxyethylenenitrilo) teraacetic acid (Ba-EGTA) is used to reduce interference due to calcium which also reacts with MTB. Expected Values, Serum Magnesium normal value was considered 1.8-2.4 mg/dl, hypomagnesemia $<1.8$, hypermagnesemia $>2.4 \mathrm{mg} / \mathrm{dl}$

Serum Calcium was lebelled as mildly low $2-2.1 \mathrm{mmol} /$ I, moderately low $1.9-2.0 \mathrm{mmol} / \mathrm{l}$,severely low $<1.9$. The calcium was measured by calcium (CA) method. The CA method used on the Dimension ${ }^{\circledR}$ clinical chemistry system is an in vitro diagnostic test intended for the quantitative determination of calcium in human serum and plasma. Serum Calcium level, mildly low $2-2.1 \mathrm{mmol} / \mathrm{l}$, moderately low $1.9-2.0 \mathrm{mmol} /$ I, severely low $<1.9$. Data were processed and analysed using software SPSS (Statistical Package for Social Sciences) version 22. The test statistics used to analyzed the data were descriptive statistics, correlation coefficient and student $t$ test. Level of significance was set at 0.05 and $p<0.05$ was considered significant.

\section{Results}

In this study, a total of 54 nephrotic syndrome children were included.Among them 25 were under $5 \mathrm{yr}, 29$ were older than 5 yr.Mean age5.51 $( \pm 2.56)$ year.Male to female ratio is $2.6: 1$. The study children were evaluated clinically for deficiency signs and symptoms of magnesium and calcium, but none of them showed any clinical signs and symptoms.

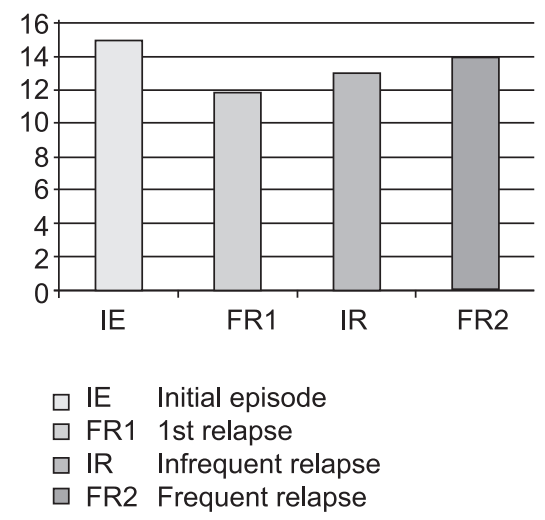

Fig.-1: Distribution of patients by type of attack 
Among nephrotic syndrome cases 15(27.8\%) patients were in initial episode, $12(22.2 \%)$ were in $1^{\text {st }}$ relapse, $13(24.1 \%)$ were in infrequent relapse and $14(25.9 \%)$ were in frequent relapse nephrotic syndrome.

24.1 percent of the patients had hypomagnesmia (< $1.8 \mathrm{mg} / \mathrm{dl}$ ) and $13.0 \%$ had hypermagnesemia (> 2.4 $\mathrm{mg} / \mathrm{dl})$. The rest of the cases had magnesium level within normal range $(1.8-2.4 \mathrm{mg} / \mathrm{dl})$ (Table-I).

Table-I

Serum magnesium and calcium level of the study population

\begin{tabular}{lccr}
\hline Magnesium level & Number & Calcium level & Number \\
\hline$<1.8$ & $13(24 \%)$ & $<1.9$ & $13(24 \%)$ \\
$1.8-2.4$ & $34(63 \%)$ & $1.9-2.0$ & $15(28 \%)$ \\
$>2.4$ & $7(13 \%)$ & $2.0-2.1$ & $26(48 \%)$ \\
\hline total & $54(100 \%)$ & total & $54(100 \%)$ \\
\hline
\end{tabular}

The mean level of serum magnesium during initial attack was $2.28 \pm 0.36 \mathrm{mg} / \mathrm{dl}$, and it was $2.04 \pm 0.29 \mathrm{mg} /$ dl during first relapse, $2.06 \pm 0.29 \mathrm{mg} / \mathrm{dl}$ during infrequent relapse and $1.76 \pm 0.32 \mathrm{mg} / \mathrm{dl}$ during frequent relapse. The difference found among the mean level of serum magnesium level in different pattern of nephrotic syndrome by ANOVA test (one way) is statistically significant $(P<0.01)$ [Table-II].

Table-II

Magnesium status in different states of nephrotic syndrome $(n=54)$

\begin{tabular}{lcc}
\hline $\begin{array}{l}\text { Type of } \\
\text { Attack }\end{array}$ & $\begin{array}{c}\text { Magnesium } \\
\text { Level }(\mathrm{mg} / \mathrm{dl}) \\
{[\text { Mean } \pm S D]}\end{array}$ & $\begin{array}{c}{ }^{*} \mathrm{P} \\
\text { value }\end{array}$ \\
\hline Initial episode $(\mathrm{n}=15)$ & $2.28 \pm 0.36$ & \\
1st relapse $(\mathrm{n}=12)$ & $2.04 \pm 0.29$ & $<0.01$ \\
Infrequent relapse $(\mathrm{n}=13)$ & $2.06 \pm 0.29$ & \\
Frequent relapse $(\mathrm{n}=14)$ & $1.76 \pm 0.32$ & \\
\hline
\end{tabular}

${ }^{*}$ ANOVA Test
The mean level of serum calcium during initial attack was $2.01 \pm 0.16 \mathrm{mmol} / \mathrm{l}$, and it was $1.98 \pm 0.17 \mathrm{mmol} / /$ during first relapse, $2.06 \pm 0.13 \mathrm{mmol} / \mathrm{l}$ during infrequent relapse and $2.05 \pm 0.15 \mathrm{mmol} / \mathrm{l}$ during frequent relapse. The difference found among the mean level of serum calcium level in different pattern of nephrotic syndrome by ANOVA test (one way) is statistically insignificant $(P>0.01)$ [Table-III].

Table-III

Calcium status in different states of nephrotic syndrome $(n=54)$

\begin{tabular}{|c|c|c|}
\hline Type of & Calcium & ${ }^{*} \mathrm{P}$ \\
\hline \multirow[t]{2}{*}{ Attack } & Level (mmol/L) & Value \\
\hline & 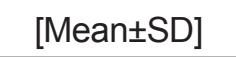 & \\
\hline Initial episode $(n=15)$ & $2.01 \pm 0.16$ & \\
\hline 1 st relapse $(n=12)$ & $1.98 \pm 0.17$ & $>0.05$ \\
\hline Infrequent relapse $(n=13)$ & $2.06 \pm 0.13$ & \\
\hline Frequent relapse $(n=14)$ & $2.05 \pm 0.15$ & \\
\hline
\end{tabular}

*ANOVA Test

Among the patients with severely low $(<1.9 \mathrm{mmol} / \mathrm{l})$ calcium level, about $30.75 \%$ of them had less than $1.8 \mathrm{mg} / \mathrm{dl}$ magnesium level, $30.75 \%$ of them had $\mathrm{mg}$ level at $1.8-2.4$ and about $38.5 \%$ had $\mathrm{mg}$ level at greater than 2.4. Among the patients with Moderately Low Calcium level, $13 \%$ had mg level at $<1.8 \mathrm{mg} / \mathrm{dl}, 53.3 \%$ had $\mathrm{mg}$ level at $1.8-2.4 \mathrm{mg} / \mathrm{dl}$ and $33.7 \%$ of the patients had $\mathrm{mg}$ level greater than $2.4 \mathrm{mg} / \mathrm{dl}$. Among the patients with mild calcium level, $23 \%$ of them had $\mathrm{mg}$ level at $<1.8 \mathrm{mg} / \mathrm{dl}, 61.5 \%$ of them had $\mathrm{mg}$ level at $1.8-2.4 \mathrm{mg} / \mathrm{dl}$ and $15.5 \%$ had $\mathrm{mg}$ level greater than $2.4 \mathrm{mg} / \mathrm{dl}$. The $\mathrm{p}$ level at 0.28 shows no significant correlation between $\mathrm{mg}$ level and calcium level (Table-IV).

Table-IV

Association between calcium level with magnesium level

\begin{tabular}{lccccc}
\hline Calcium level $(\mathrm{mmol} / \mathrm{l})$ & \multicolumn{3}{c}{ Magnesium level $(\mathrm{mg} / \mathrm{dl})$} & Total & p value \\
\cline { 2 - 4 } & $<1.8$ & $1.8-2.4$ & $>2.4$ & & \\
\hline Severe $(<1.9)$ & $4(30.75 \%)$ & $4(30.75 \%)$ & $5(38.5 \%)$ & $13(100 \%)$ & 0.28 \\
Moderate $(1.9-2)$ & $2(13 \%)$ & $8(53.3 \%)$ & $5(33.7 \%)$ & $15(100 \%)$ & \\
Mild $(2-2.1)$ & $6(23 \%)$ & $16(61.5 \%)$ & $4(15.5 \%)$ & $26(100 \%)$ & \\
\hline Total & 12 & 28 & 14 & 54 & \\
\hline
\end{tabular}

${ }^{*}$ Chi-square test 


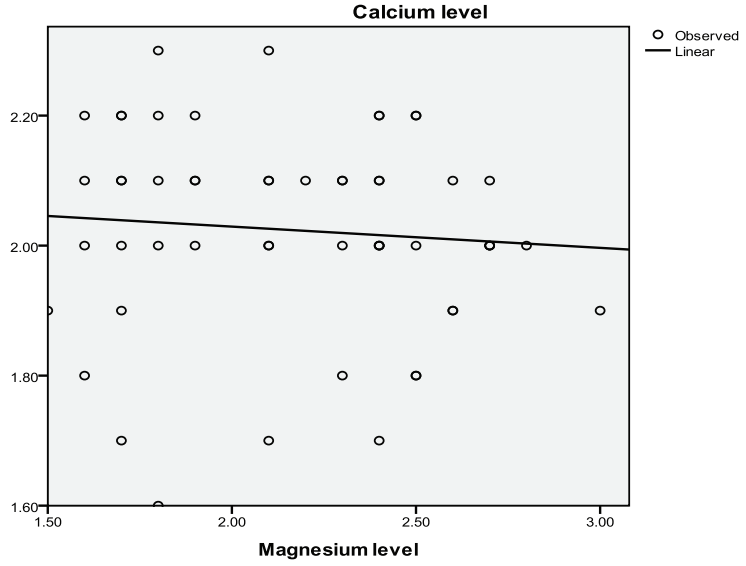

Fig.-2: Correlations of serum magnesium with calcium in children with nephrotic syndrome.

Magnesium is low in most cases of frequent relapse nephrotic syndrome patients. There was no significant correlation between calcium level with magnesium level $(r=-0.08, p=0.28)$.

\section{Discussion}

Some studies reported normal serum calcium levels in NS patients. ${ }^{10-12}$ In study of Winata et al ${ }^{13}$ showed that the calcium level of NS children was lower than that in healthy children. The Hossain A et $\mathrm{al}^{14}$ study also support Winata et al. study they found ionized calcium level of NS children was lower than that in healthy children. This may be due to the decrease in ionized calcium in NS children occurs subsequently during the course of diseases associated with timing of proteinuria. Hooft et $\mathrm{al}^{15}$ observed that the ionized calcium in nephrotic syndrome children decrease after having proteinurea for more than two months. Choi et al ${ }^{16}$ also found a very weak positive correlation between the duration of disease and ionized calcium level from their 14 nephrotic syndrome samples. Garniasih et $\mathrm{al}^{17}$ found positive correlation between serum albumin level and total serum calcium in children. There was $50 \%$ of ionized calcium in total serum calcium, so when the total serum calcium level decreased then the ionized calcium level also decreased.

There is however, meagre information available concerning magnesium metabolism in the nephrotic syndrome. Kobayashi $\mathrm{A}^{18}$ study revealed that serum magnesium level was significantly reduced in the untreated condition of the disease. Serum magnesium level was gradually elevated to the normal range as the disease improved.

Prasad et al ${ }^{19}$ described that in the nephrotic syndrome the total magnesium was some what lower than normal, probably because of hypoprotinaemia and that the percentage of ultrafiltrable magnesium was increased in some patients associated with hypoalbunaemia.

In one of the first cases of primary hyperaldosteronism reported, a very low serum magnesium. ${ }^{20}$

Present study reveals that, hypomagnesemia is mostly found in frequent relapse nephrotic syndrome cases. This may be partly due to secondary hyperaldosteronism which is thought to develop in nephrotics with generalized oedema and partly due to loss of protein.

Our study also shows there is no significant association between calcium level with magnesium level $(p>0.05)$.

\section{Conclusion}

Hypomagnesemia is mostly found in frequent relapse nephrotic syndrome cases. There was no significant association between calcium level with magnesium level.

\section{Recommendation}

Furthur study should be done to look for any renal structural abnormality particularly tubular problem in those patients. Further multicentred randomized study should be under taken.

\section{References}

1. Winata VI, Gurnida DA, Sekarwana N. Relationship between ionized calcium and serum albumin level in children with idiopathic nephrotic syndrome. Paediatr Indones. 2010; 50:361-64.

2. Rude A, Wester C, Saris. Dietary Supplement Fact Sheet: Magnesium. Washington: Food and Nutrition Board; 1999. 8p. Report No: 2.

3. Gowenlock AH, McMurray JR, Mclauchlan DM. Varley's Practical Clinical Biochemistry, 5th Ed. Heinemann Medical: London, UK. 1988;1: 408-10.

4. Craing GC, Willis NC, Hodson EM. Incidence of Nephrotic Syndrome in Children in Australia.Pediatr Nephrol. 2000; 11: 111-6. 
5. Goldstein DA, Haldimann B, Sherman D, Norman AW, Massry SG (1981) Vitamin D metabolites and calcium metabolism in patients with nephrotic syndrome and normal renal function. J Clin Endocrinol Metab.1972; 52: 116-121.

6. Garniasih D. The relationship between serum albumin and calcium in Children with Nephrotic Syndrome. Sari Pediatrics.2011;10: 100-106.

7. Paunier L. Effect of magnesium on phosphorus and calcium metabolism. Monatsschr Kinderheilkd. 1992;140(9 suppl 1):17-20.

8. Ghai OP, Gupta P, Paul VK. Fluid and electrolytes. In Ghai Essential Pediatircs (6th edn) Revised and Enlarged. CBS. 2005;8:88-89.

9. Choi DH, Clin DK, Lee JB, Kim PK. Calcium metabolism in nephrotic syndrome of children. Korean J Nephrol.1987; 6: 311-19

10. Lambert PW, De Oreo PB, Fu IY, Kaetzel DM, Von Ahn K, Hollis BW, et al. Urinary and plasma vitamin $D<$ sub $>3$ metabolites in the nephrotic syndrome. Metabolic Bone Disease and Related Research.1982;4:7-15.

11. Mittal SK, Dash SC, Tiwari SC, Agarwal SK, Saxena S, Fishbane S. Bone histology in patients with nephrotic syndrome and normal renal function. Kidney international. 1999; 55:1912-29.

12. Panczyk-Tomaszewska M, Adamczuk D, Kisiel A, Skrzypczyk P, Przedlacki J, Gorska E, et al. Markers of bone metabolism in children with nephrotic syndrome treated with corticosteroids. Advances in experimental medicine and biology. 2015;840:21-28.
13. Winata VI, Gurnida DA, Sekarwana N. Relationship between ionized calcium and serum albumin level in children with idiopathic nephrotic syndrome. Paediatr Indones. 2010; 50:361-64

14. Hossain A, Mostafa G, Mannan KA, Prosad Deb $\mathrm{K}$, Hossain MM et al. Correlation Between Serum Albumin Level and Ionized Calcium in Idiopathic Nephrotic Syndrome in Children. Urol Nephrol Open Access J. 2015; 3: 70-71.

15. Hooft C, Vermassen A, Van BM. On calcaemia and phosphataemia in the nephrotic syndrome. Comparative study of the periods before and after the introduction of hormone therapy. Helv Paediatr Acta. 1960;15: 437-50.

16. Choi DH, Clin DK, Lee JB, Kim PK. Calcium metabolism in nephrotic syndrome of children. Korean J Nephrol. 1987; 6: 311-19.

17. Garniasih D. The relationship between serum albumin and calcium in Children with Nephrotic Syndrome. Sari Pediatri.1983; 10: 100-105.

18. Kobayashi A. Serum magnesium level in Idiopathic nephrotic syndrome. Paediatric Univ Tokyo.1968;15:12-6.

19. Prasad AS, Flink FB, McCollister R. Ultrafiltration studies on serum magnesium in normal and diseased states, J. Lab \& clin Med. 1961;58: 531-32.

20. Horton R, Biglieri EG. Effect of aldosterone on the metabolism of magnesium. J Clin Endocrinol Metab. 1962;22:1187-92. 